\title{
Pelatihan Maintance Komputer SMK Negeri 1 Pagar Alam
}

\author{
Alfis Arif ${ }^{1}$, Yogi Isro' Mukti ${ }^{2}$ \\ Program Studi Teknik Informatika; Sekolah Tinggi Teknologi Pagaralam (STTP) \\ Jl. M. Siagim No.75 Kel. Karang Dalo, Dempo Tengah, Kota Pagar Alam \\ Telp/Fax: (0730) 621916 \\ e-mail: alfisarif@yahoo.com¹. Yogie.Isro.mukti@gmail.com².
}

\begin{abstract}
Abstrak
Mata pelajaran maintenance komputer merupakan keahlian yang harus dimiliki siswa SMKN 1 Kota Pagar Alam, dan praktikum maintenance yang diadakan laboratorium komputer SMKN 1 Kota Pagar Alam dianggap belum maksimal karena waktu yang terbatas sehingga civitas akademika STTP dan pimpinan SMKN 1 Kota Pagar Alam menggap perlu pelatihan diluar jam pelajaran dan jam praktikum, dan dengan semangat berbagi berdasarkan prinsif Pengabdian pada Tri Dharma maka civitas akademika membantu pelatihan diluar pelajaran dan praktikum sekolah. Metode yang digunakan dengan praktek secara langsung dan siswa yang tidak paham dapat langsung bertanya pada narasumber. Pada pelaksanaannya menggunakan metode pre dan pos tes untuk efektifitas pelatihan, dari pre tes diketahui siswa memahami tentang maintenance tetapi masih banyak bagian materi yang belum benar-benar dipahami sehingga ini menjadi kesempatan bagi civitas STTP untuk melakukan pengabdian. Pada akhir pelatihan dilakukan pos tes hasilnya siswa mampu memahami dan menjelaskan kembali materi dan mampu paham dengan baik perangkat keras dan perangkat lunak komputer.
\end{abstract}

Kata kunci-Maintenance, Civitas, Praktikum, Siswa, STTP, Komputer.

\section{PENDAHULUAN.}

Pada saat ini perkembangan Teknologi informasi dan komunikasi (TIK) terutama teknologi pendukung terlaksananya pekerjaan sangat banyak dan menawarkan kemudahan-kemudahan sesuai ke unggulannya, salah satunya adalah teknologi sistem komputer ini dapat di manfaatkan untuk berbagai kegiatan, hampir tidak ada yang tidak bisa dikerjakan komputer, terbukti seluruh kegiatan manusia saat ini hampir segalanya, segala kegiatan, segala profesi sudah menggunakan komputer dan mengaplikasikan program tertentu dari mulai komputer atau program yang sangat sederhana sampai dengan sistem komputer dan program dengan konfigurasi yang sangat kompleks, dari komputer yang tidak saling terhubung (personal), tergabung pada jaringan LAN, MAN, dan WAN, dari software hanya di aplikasikan satu PC sampai dengan sistem yang terdistribusi dan client server, tentunya itu semua untuk mendukung kegiatan manusia, untuk memudahkan.

Pelatihan pengelolaan sistem dan maintenance komputer ini merupakan pemberian pemahaman awal bagi pengelolaan komputer diharapkan walau pun para siswa ini, siswa daerah tetapi dapat mandiri, artinya diharapkan pada saat nanti turun di dunia kerja Alumni SMKN 1 Kota Pagar Alam ini tak hanya menjadi pemakai sistem komputer saja tetapi selain pemakai pada saat terjadi kerusahan atau kekurangan yang terjadi pada sistem komputernya mereka tidak tergantung pada pihak lain, dalam hal ini mampu menanganinya terlebih dahulu tanpa bantuan pihak lain, kecuali apa bila terjadi ke rusakan yang memerlukan penanganan yang khusus sebab itu maka pelatihan ini terlaksana, pada dasarnya seluruh sistem pembelajaran sudah termasuk tentang pengelolaan dan maintenance ini tetapi untuk memberikan kesempatan kepada dosen STTP untuk berbagi dan mungkin terdapat sesuatu yang terlewati atau terlupakan oleh guru di dalam kelas maka SMKN 1 Kota Pagar Alam menyambut baik terlaksananya pengabdian ini.

Selain itu Kondisi geografis dan fasilitas teknologi informasi (TI) yang belum memadai di Pagar Alam berimbas pada tingkat pemahaman dan penalaran terhadap sesuatu hal baru agak 
terhambat, STT Pagaralam sebagai Pionir dan dianggap lembaga yang kompeten terus mengikuti perkembangan teknologi informasi yang ada, dan kewajiban melakukan pengabdian seperti yang di amanatkan oleh jargon Tri dharma di atas, maka diadakanlah pengabdian yang kegiatannya pelatihan maintenance ini, sebenarnya upaya untuk berbagi dan saling memahamkan terhadap suatu ilmu yang di rasa oleh Para siswa dan Guru SMKN 1 Kota Pagar Alam kurang. Dari pemaparan diatas dituntut agar para siswa SMKN 1 Kota Pagar Alam harus selalu meningkatkan kualitas pemahaman terhadap Teknologi informasi dengan menggunakan semua resource terkait, sehingga dipandang perlu untuk diadakan pelatihan Maintenance di lingkungan SMKN 1 Kota Pagar Alam ini.

\section{METODE.}

Pelaksanaan pengabdian ini dilakukan dosen STTP dilakukan secara mandiri, dan bersamaan dengan kuliah kerja nyata (KKN) yang dilakukan mahasiswa sehingga pelaksanaan mahasiswa membantu dosen melaksanakan pengabdian. Metodologi pelaksanaan kegiatan Pengabdian kepada masyarakat (PkM) ini: menyimak (menonton) bersama, membaca bersama (modul pelatihan), memahami tools aplikasi (Software) dan berinteraksi secara langsung (Aplikatif) dengan software.

\subsection{Pengabdian Pada Masyarakat (PkM).}

Program kegiatan Pengabdian masyarakat merupakan suatu program kegiatan yang bertujuan membantu masyarakat umum dalam aktivitas tanpa mengharapkan imbalan dalam bentuk apapun. Secara umum program ini dirancang lembaga perguruan tinggi untuk memberikan kontribusi nyata bagi masyarakat, khususnya dalam mengembangkan kesejahteraan dan kemajuan negara. Kegiatan Pengabdian Masyarakat merupakan salah satu bagian Tri Dharma Perguruan Tinggi. Bentuk-bentuk kegiatan Pengabdian Masyarakat bisanya berupa: Bakti Sosial dan Mengajar. Tujuan Pengabdian Masyarakat di Perguruan Tinggi, yaitu:

1. Dapat melakukan alih teknologi, ilmu, dan seni kepada masyarakat untuk pengembangan martabat manusia dan kelestarian sumber daya alam.

2. Meningkatkan inovasi teknologi informasi untuk mendorong pembangunan ekonomi dengan melakukan komersialisasi hasil penelitian yang dihasilkan;

3. Dapat memberikan solusi berdasarkan kajian akademik atas kebutuhan, tantangan, atau persoalan yang dihadapi masyarakat, baik secara langsung maupun tidak langsung;

4. Melaksanakan program kegiatan yang mampu mengentaskan masyarakat tersisih (preferential option for the poor) pada semua strata, yaitu masyarakat yang tersisih secara ekonomi, politik, sosial, dan budaya;

\subsection{Teknologi Informasi.}

Teknologi Informasi secara etimologi berasal dari kata Information Technology. Kata Technology berdasarkan Kamus Advanced Leaner's Dictionary of Current English (1974) adalah penerapan pengetahuan secara sistematis pada tugas praktis dalam suatu industri. Senada dengan definisi itu, Sulistyo-Basuki (1992:81) menyatakan Teknologi diartikan sebagai pelaksanaan ilmu, sinonim dengan ilmu terapan. Kata Informasi pada Oxford Advanced Learners's Dictionary of Current English (1980: 437), diartikan sesuatu yang diberitahukan, pengetahuan, dan berita. Sedang Ilmu Informasi, kata "Informasi", "pengetahuan", dan "berita" dibedakan. Menurut Teskey (Pendit,1992) data adalah hasil observasi langsung terhadap suatu kejadian, merupakan perlambangan mewakili objek atau konsep di dunia nyata, yang dilengkapi dengan nilai tertentu; Informasi adalah kumpulan data terstruktur, disampaikan seseorang pada orang lain. Sedangkan berita menurut Arifin (1997), adalah informasi menarik, penting dan belum pernah didengar. Informasi merupakan sarana baku untuk menunjang dan meningkatkan kegiatan bidang Ilmu Pengetahuan, kebudayaan dan teknologi. Pengetahuan, adalah sesuatu digunakan manusia untuk memahami dunia, yang bisa diubah berdasarkan informasi yang diterima. Pada laporan ini informasi secara singkat diartikan sebagai segala data, fakta $\&$ pengetahuan disampaikan kepada orang lain melalui berbagai media, dalam bentuk tekstual, gambar, maupun suara.

Teknologi informasi sebuah istilah baru yang merupakan terjemahan dari Information Technology bagi kebanyakan orang teknologi informasi merupakan sinonim dari "Teknologi 
Baru", karena kaitannya erat dengan mesin microprosesor, seperti mikro-komputer, alat yang bekerja otomatis, seperti alat pengolah kata, dan lain sebagainya . Pengertian Teknologi Informasi berdasarkan British Advisory Council for Applied Research and Development (Zorkoczy, (1990: 12) adalah meliputi bidang ilmu pengetahuan, teknologi dan perekayasaan serta teknik pengelolaan yang digunakan pada penanganan dan pengolahan informasi, penerapan bidang dan teknik tersebut, komputer dan interaksinya dengan manusia dan mesin, masalah sosial ekonomi serta budaya yang berkaitan. Memang banyak definisi-definisi tentang Teknologi Informasi, sehingga dalam "Macmillan Dictionary of Personal Computing and Communication" terdapat empat halaman menjelaskan Teknologi Informasi.

\subsection{Maintenance.}

Maintenance merupakan kegiatan pemeliharaan dan perbaikan jika ada harus di perbaiki terhadap suatu perangkat atau sistem tertentu, dalam hal ini merupakan sistem komputer, maintenance merupakan pemeliharaan atau perbaikan rutin, dengan adanya maintenance sistem komputer atau jaringan komputer dapat terhindar dari kerusakan yang sangat parah, karena sebelum terjadi kerusakan, hal yang tidak diinginkan terjadi pada sistem komputer telah diantisipasi dahulu.

\subsection{Pre \& Pos Tes.}

Pre tes yaitu suatu bentuk pertanyaan, dilontarkan guru pada murid sebelum memulai suatu pelajaran. Pertanyaan yang ditanya yaitu materi yang diajar pada hari itu (materi baru). Pertanyaan itu biasanya dilakukan guru di awal pembukaan pelajaran. Pre tes diberikan dengan maksud mengetahui apakah ada diantara murid sudah mengetahui mengenai materi diajarkan. Pre tes juga bisa diartikan sebagai kegiatan menguji tingkatan pengetahuan siswa terhadap materi yang akan disampaikan, kegiatan pre tes dilakukan sebelum kegiatan pengajaran diberikan. Adapun manfaat dari diadakannya pre tes untuk mengetahui kemampuan awal siswa mengenai pelajaran yang disampaikan. Dengan mengetahui kemampuan awal siswa ini, guru mampu menentukan cara penyampaian pelajaran yang di tempuhnya nanti.

Post tes merupakan bentuk pertanyaan yang diberikan setelah pelajaran/materi telah disampaikan. Singkatnya, post tes yaitu evalausi akhir saat materi di ajarkan pada hari itu telah diberikan, guru memberikan post tes dengan maksud apakah murid sudah mengerti dan memahami mengenai materi baru saja diberikan pada hari itu. Manfaat diadakannya post tes ini untuk memperoleh gambaran tentang kemampuan yang dicapai setelah berakhir penyampaian pelajaran. Hasil post tes ini dibandingkan dengan hasil pre tes yang telah dilakukan sehingga diketahui seberapa jauh efek atau pengaruh dari pengajaran yang dilakukan, disamping sekaligus dapat diketahui bagian mana dari bahan pengajaran yang belum dipahami oleh sebagian besar siswa.

\subsection{Penyelesaian Masalah.}

Sehingga sesui dengan permasalahan ini maka perlu dilakukan pelatihan editing gambar (photo) menggunakan aplikasi yang familiar, ini di yakini bisa menambah softskills dan kepercayaan diri alumni SMA Gumay sehingga tidak hanya masalah atau pelajaran umum saja yang dipahaminya tetapi mendapat pelajaran tambahan dalam menghadapi perkembangan zaman pada masyarakat.

\section{PEMBAHASAN DAN HASIL.}

3.1. Realisasi \& Pemecahan Masalah.

Pelatihan dilakukan pada siswa SMKN 1 Kota Pagar Alam oleh civitas STTP diharapkan menyelesaikan permasalahan yang dihadapi pihak SMKN 1 Kota Pagar Alam terutama dalam pelajaran maintenance, maintenance menjadi sangat penting bagi siswa untuk jurusan komputer dan komputer jaringan karena menjadi inti dari pembelajaran, pembelajaran maintenance sebanrnya sudah dilaksanakan dengan sangat sesuai standar, dan dirasakan oleh Guru dan siswa pembelajaran dikelas sudah sangat baik memahamkan dari sisi teori tetapi sebagai produk SMK maka praktek harus menjadi nilai tambah yang harus menjadi nilai tambah paling utama sehingga pelatihan diluar jam pelajaran menjadi sangat diperlukan, sehingga pihak sekolah bersama dengan 
pengabdi dari STTP menyelenggarakan pelatihan dengan rincian pelatihan seperti terdeskripsi pada tabel 1 dibawah ini, menjelaskan dengan sangat detail kegiatan pengabdian yang dilakukan.

Tabel 1. Kegiatan

\begin{tabular}{|l|l|c|}
\hline \multicolumn{1}{|c|}{ Waktu } & \multicolumn{1}{|c|}{ Materi } & Penyaji \\
\hline $08.00-09.00$ & Pre Test & \\
$09.00-09.30$ & $\begin{array}{l}\text { Pengenalan perangkat keras komputer dan lunak } \\
\text { komputer }\end{array}$ & \\
\hline $09.30-12.00$ & $\begin{array}{l}\text { Mempelajari set up dan tips serta trik maintenance } \\
\text { sederhana, reset bios, tips dan trik instalasi. }\end{array}$ & Arif \\
$12.00-12.30$ & Ishoma & \\
$12.30-13.00$ & Post-test & \\
\hline
\end{tabular}

Berdasarkan tabel 1. Rincian kegiatan yang dilakukan pada saat pengabdian di SMKN 1 Kota Pagar Alam, pelatihan diawali denga pre tes, pre tes untuk mengetahui pemahaman peserta pelatihan agar materi yang disampaikan sesuai dengan kebutuhan dari para siswa peserta pelatihan dan benar-benar menjadi keahlian khusus yang dimiliki para alumni SMKN 1 Kota Pagar Alam, setelah dilakukan tes berikutnya dilakukan pengenalan hal-hal yang sangat penting (urgent) dari perangkat keras komputer, yang diperkirakan sering mengalami trouble pada komputer, tip dan trik cara mengatasinya, mengenalkan tips dan trik ketika mengalami permasalahan dari sisi software misalnya permasalahan pada bios dan lain-lain.

Berikutnya setelah hardware dan software yang krusial sudah dipahami dan paham cara mengatasi permasalahan dijika ditemukan pada saat sistem komputer dijalankan berikutnya mempelajari secara langsung bagaimana melakukan set up, atau up grade terhadap sistem komputer, memahami cara melakukan reset, tip dan trik untuk instalasi, tips dan trik ketika ada badsector, permasalah sistem operasi, cara meremov aplikasi sampah yang tersisa dan sebagainya. Terakhir dilakukan tes lagi untuk mengetahui kemampuan peserta pelatihan terhadap materi yang disampaikan oleh narasumber tentu untuk mengetahui tingkat keberhasilannya yaitu dengan membandingkan nilai yang di peroleh pos tes ini dengan pre tes, jika pemahaman peserta pelatihan tinggi di pos tes dan rendah di pre tes artinya pelatihan yang dilakukan berhasil dilakukan, dan hasil ini menjadi masukan bagi LPPM STTP untuk pengembangan dan perbaikan pelaksanaan pengabdian yang dilakukan oleh dosen dan civitas STTP lainnya.

\subsection{Pembahasan \& Hasil.}

Pelatihan dilakukan dengan melakukan pre tes dahulu dan hasilnya dari seluruh peserta pelatihan cukup baik memahami teori sehingga narasumber tinggal menjelaskan bagian-bagian tertentu saja yang memerlukan penjelasan tambahan karena secara umum peserta sudah mendapatkannya didalam kelas tetapi secara praktek peserta merasa kurang sehingga dengan adanya pelatihan peserta merasa senang dan belajar dengan semangat, sehingga peserta lebih fokus dengan materi yang disampaikan narasumber, berikutnya pengenalan hardware dan software yang krusial mudah mengalami kerusakan atau error dan hasilnya karena mereka sudah memperoleh dasar pembelajaran dalam kelas sehingga mudah menyerap materi, berikutnya peserta diminta untuk melakukan set up beberapa bagian di hardware dan software komputer, pada bagian ini pun siswa peserta cukup mudah dan cepat memahaminya, cara melakukan up grade dan melakukan instalasi pada software. Terakhir dilakukan tes untuk mengetahui tingkat keberhasilan dan nyata siswa peserta pelatihan sangat menguasai materi yang disampaikan, berikut rincian dalam bentuk tabel yang disusun secara berurutan.

Tabel 2. Pelaksanaan Kegiatan

\begin{tabular}{|l|l|}
\hline \multicolumn{1}{|c|}{ Materi } & \multicolumn{1}{|c|}{ Hasil } \\
\hline Pendahuluan & $\begin{array}{l}\text { Pendahuluan dilakukan pre tes, mengetahui arah } \\
\text { pembelajaran agar sesuai dengan kebutuhan peserta pelatihan } \\
\text { yang dilakukan pada SMKN 1 Kota Pagar Alam. }\end{array}$ \\
\hline Pengantar perangkat keras dan & Peserta memahami perangkat keras dan lunak lebih baik agar \\
\hline
\end{tabular}


NGABDIMAS - Jurnal Pengabdian Kepada Masyarakat Vol.02, No. 02, Desember 2019, Hal.90-95

\begin{tabular}{|l|l|}
\hline lunak komputer & $\begin{array}{l}\text { mereka benar-benar ahli dalam bidang maintenance sehingga } \\
\text { pada saat permasalahan dapat diselesaikan dengan segera. }\end{array}$ \\
\hline $\begin{array}{l}\text { Mempelajari set up, tip upgrade, } \\
\text { dan maintenance, }\end{array}$ & $\begin{array}{l}\text { Peserta memahami cara set up, memiliki kemampuan } \\
\text { melakukan upgrade komputer sehingga komputer yang } \\
\text { dipakainya memiliki spesifikasi yang tidak ketinggalan } \\
\text { sehingga tetap mampu mengerjakan tugas-tugasnya. }\end{array}$ \\
\hline Tips dan trik instalasi & $\begin{array}{l}\text { Peserta paham dengan tip mengintalasi yang baik sehingga } \\
\text { penambahan yang biasa tidak mempengaruhi atau } \\
\text { membebani kinerja komputer secara umum bahkan mampu } \\
\text { mengerjakan hal yang rumit. }\end{array}$ \\
\hline Penutup & $\begin{array}{l}\text { Bagian akhir ini yang dilakukan narasumber dalam pelatihan, } \\
\text { gunanya untuk mengetahui pemahaman peserta terhadap } \\
\text { materi yang disampaikan hasilnya dibandingkan dengan hasil } \\
\text { pre tes. }\end{array}$ \\
\hline
\end{tabular}

Dari sini bisa di pahami hasil dari kegiatan pengabdian yang dilakukan ini softskills para peserta siswa dan siswi yang mengikuti pelatihan meningkat dengan sangat baik dan pelatihan berhasil dengan sangat baik, sehingga peserta pelatihan menjadi lebih optimis dalam menghadapi masa depannya ini memberikan keuntungan bagi SMKN 1 Kota Pagar Alam karena masyarakat semakin percaya dan bagi STTP dengan pengabdian dan pelatihan ini mendapat calon atau peminat baru untuk kuliah di STTP dan lebih meningkatkan kepercayaan pada kemampuan alumni yang sangat baik, sehingga bisa diidentifikasi berikut merupakan hasil akhirnya, yaitu:

a. Para peserta siswa dan siswi SMKN 1 Kota Pagar Alam mempunyai pengetahuan dan pemahaman yang baik tentang maintenance sistem komputer.

b. Seluruh siswa dan siswi SMKN 1 Kota Pagar Alam menjadi sangat paham terhadap teknologi informasi yang lebih aplikatif untuk mendukung pekerjaanya.

c. Para guru SMKN 1 Kota Pagar Alam sudah terbantu dalam pemberian pemahaman terhadap teknologi informasi up to date yang aplikatif.

d. Para siswa dan siswi peserta pelatihan lebih memahami lagi tentang aplikasi pembelajaran maintenance yang disampaikan oleh guru didalam kelas, jauh lebih memahami secara lebih aplikatif.

e. Para siswa siswi peserta pelatihan menjadi lebih merasa percaya diri saat terjun pada dunia kerja dan lebih memiliki pemahaman pada siswa dan siswi yang melanjutkan studi keperguruan tinggi jelas pembelajaran ini menjadi pemahaman awal dalam bergaul pada perkuliahan di kampus.

\section{KESIMPULAN}

Pelaksanaan pengabdian masyarakat ini yang dilakukan di SMKN 1 Kota Pagar Alam dengan tujuan melatih siswa dan siswi dalam melakukan maintenance pada sistem komputer didapatkan kesimpulan sebagai berikut:

a. Menambah softskills siswa-siswi SMKN 1 Kota Pagar Alam dalam maintenance computer.

b. Proses pembelajaran dengan belajar aplikasi secara langsung ternyata mampu meningkatkan semangat siswa belajar menjadi lebih baik (giat).

c. Meningkatkan rasa percaya diri siswa dengan kemampuannya ketika terjun di masyarakat.

d. Membantu guru pelajaran TIK dalam hal memahamkan siswa terhadap suatu aplikasi tertentu terutama maintenance kompute.

\section{SARAN}

Berdasarkan pengalaman yang dilihat dan dirasakan penulis saat melakukan pengabdian pelatihan maintenance pada SMKN 1 Kota Pagar Alam ini maka, penulis dalam hal ini bisa memberikan saran: 

a. Menambah instansi tempat pengabdian lebih banyak
b. Pendanaan pengabdian lebih mudah pencairan.
c. Lebih banyak mahasiswa membatu.

\section{UCAPAN TERIMA KASIH}

Terima kasih semua pihak.

\section{DAFTAR PUSTAKA}

[1] Sadiman, A.S., Rahardjo, R., Haryono, A., \& Rahardjito. 2006. Media pendidikan: Pengertian, pengembangan, dan pemanfaatan. Jakarta: Rajagrafindo Persada.

[2] Muslim, B. 2018. Pelatihan aplikasi editing video dengan filmora., Laporan Pengabdian Kepada Masyarakat, LPPM STT Pagaralam.

[3] Indonesia Services Education HP Tim, 2001, Manajemen Sistem Belajar Di Dunia Maya, Majalah Info Komputer.

[4] Muslim, B. 2018. Pelatihan Pembuatan Blog Bagi Guru Ma Ponpes Darul Mutaqin Kota Pagaralam. NGABDIMAS. Vol 1. No.1. Bulan Juni, Hal. 6-11

[5] B. Muslim, Pengantar teknologi informasi. Yogyakarta: Deepublish, 2017.

[6] Muslim, B. (2018). Analisis system informasi (SI) terintegrasi di Perguruan Tinggi (PT) (Studi Kasus: STT Pagaralam). Jurnal Teknologi Informasi MURA, Vol 10. Page 83-91.

[7] Muslim, B (2014). Analisis rencana aplikasi teknologi informasi pada STT Pagar Alam. Proseding semnastik dan Magma. Issue: Aplikasi Teknologi dan sistem Informasi. PPP UBD Pres. Pages 397-404.

[8] Hutchinson E. Sarah and Sawyer C. Stacey, 2000, Computers, Communications \& Information, McGraw Hill Companies Inc.

[9] M.H Jogiyanto, 1995, Pengenalan Komputer, Andi Offset Yogyakarta.

[10] Horsley, M., Knight, B., \& Huntly, H. 2010. The role of textbooks and other teaching and learning resources in higher education in Australia: Change and continuity in supporting learning. IARTEM 1-Journal. 3(2). 43-61.

[11] Menristekdikti. 2016. Panduan Pelaksanaan Penelitian dan Pengabdian Masyarakat di Perguruan Tinggi Edisi X Tahun 2016. hlm. 4 